Article

\title{
m-Banking Quality and Bank Reputation
}

\author{
Mirjana Pejić Bach ${ }^{1, *(\mathbb{D})}$, Berislava Starešinić ${ }^{2}$, Mislav Ante Omazić $^{1}{ }^{\mathbb{D}}$, Ana Aleksić ${ }^{1}$ (D) \\ and Sanja Seljan ${ }^{3}$ \\ 1 Faculty of Economics and Business, University of Zagreb, 10000 Zagreb, Croatia; \\ momazic@net.efzg.hr (M.A.O.); aaleksic@efzg.hr (A.A.) \\ 2 Privredna banka Zagreb, 10000 Zagreb, Croatia; berislava.staresinic@pbz.hr \\ 3 Department of Information and Communication Sciences, Faculty of Humanities and Social Sciences, \\ University of Zagreb, Ivana Lučića 3, 10000 Zagreb, Croatia; sanja.seljan@ffzg.hr \\ * Correspondence: mpejic@efzg.hr; Tel.: +385-1-2383-464
}

Received: 26 April 2020; Accepted: 22 May 2020; Published: 25 May 2020

\begin{abstract}
Banking is developed to support the clients in using various banking services, by using their mobile phones, thus allowing them to overcome the barriers in terms of time and location. Clients are increasingly using m-banking, so for some of them, this is the most used way of communication with the bank and doing banking transactions. Therefore, high-quality m-banking services significantly impact trust towards the bank, and it can influence bank reputation. Given the influence of m-banking, as well as the importance of its perceived quality, the paper aims to investigate the elements of $\mathrm{m}$-banking quality, and to analyze the relation between $\mathrm{m}$-banking quality and bank reputation. We investigate several dimensions of m-banking (safety, simplicity, and variety of $\mathrm{m}$-banking services), and their impact on perceived m-banking quality. Besides, we examine the effect of perceived m-banking quality to bank reputation. For the analysis of these relationships, we use structural equation modeling, based on the survey results on a sample of clients of major banks in Croatia. Results of empirical research indicate that safety, simplicity, and a variety of m-banking services have a significant impact on the perceived m-banking quality, which, in turn, has a positive impact on the bank's reputation.
\end{abstract}

Keywords: m-banking; service quality; bank reputation; ICT in banks

\section{Introduction}

Increased intensity of competition and globalization in the banking sector, together with technological advancements, has changed banks' approach to clients. To increase the level of client retention, banks are trying to find new sources of competitive advantage, unique capabilities, products, services, or distribution channels that will make them recognizable and distinct on the market.

A growing body of research emphasizes reputation as a specific organizational resource that can have a strategic value for organizations [1,2]. As such, reputation also became critical and particularly important for banks [3,4]. Bank transactions are based on trust, they are the so-called credence goods [5], intangible, which makes their assessment before the transaction very difficult $[6,7]$. Consequently, the decision to do business with a particular bank is strongly influenced by bank reputation. For banks, as service organizations, one of their major strategic goals, therefore, is to exploit, sustain, and defend their reputation [5].

Technological innovations have brought about fundamental changes in the concept of reputation since the reputation cannot be maintained without consistent and timely application of new technology [8]. For banks, intense demand for increasingly sophisticated products and services is driving them to move from their traditional forms and operations, shifting their focus towards making information technology an integral part of their operations and services $[9,10]$. Consequently, 
it offers a diverse portfolio of competitive products and services through technology-driven distribution channels, such as m-banking, which allows them to compete on a global level [11].

Most of the banks have included m-banking as part of their strategic directive [9]. Compared to traditional or internet banking, m-banking offers benefits such as freedom from time and place, thus supporting the efficiency of banking transactions [12].

However, m-banking, as the new distribution channel for banking operations, present a challenge for reputation management. Development of m-banking remains an important tool for building the reputation of banks, retention of existing, and attraction of new clients [13]. Therefore, the impact of $\mathrm{m}$-banking to bank reputation is an important issue. Moreover, it is necessary to analyze which elements contribute to the quality of $\mathrm{m}$-banking service, and consequently, impact bank reputation.

However, very little or no research effort has been done to investigate elements of m-banking quality [14]. There are numerous studies regarding the determinants of computer and internet-based banking, e.g., [15-17]. However, little similar research has been done regarding $\mathrm{m}$-banking. So far, research has focused on determinants of $m$-banking adoption and usage, e.g., [18-20] or influence of m-banking on client loyalty [21] and satisfaction [22]. Therefore, the purpose of this paper is to analyze the relation between m-banking quality and bank reputation, as well as to investigate elements of $\mathrm{m}$-banking quality. We analyze safety, simplicity, and variability, as specific dimensions of $\mathrm{m}$-banking service quality, as well as the impact of perceived m-banking quality to the bank reputation. For that purpose, we have conducted survey research on a sample of clients from the largest Croatian banks. Although focused on a local financial market, it is necessary to emphasize that results of the research from Croatia can be significant for larger financial markets, as trends regarding $\mathrm{m}$-banking in Croatia follow the trends in European countries [23]. Given the identified global trends, it can be seen that there is a significant potential for growth in the importance of mobile transactions and that further development and understanding of this channel of communication with the bank will be an important element in gaining a competitive advantage in the financial market of Croatia but also wider. The collected data were analyzed using structural equation modeling. The conclusions are used as the basis for the various theoretical and practical implications.

The paper is organized as follows. After the introduction, the literature review is presented, focusing on the bank reputation and quality of m-banking. The research model is elaborated in the third part of the paper, focusing on the development of the research hypothesis. The methodology of the research is presented in the fourth part of the paper, starting with the outline of the research instrument and data collection, and followed by a detailed description of the data analysis. The result section starts with the validity and reliability analysis, then focusing on the assessment of the model fit and hypothesis testing. The final section presents the conclusion of the paper in light of its theoretical and practical contributions.

\section{Literature Review}

\subsection{Bank Reputation}

In the banking sector, financial operations are mainly based on trust [24], and services provided by banks can only be evaluated with use and over time, and pre-purchase evaluation of service quality is necessarily vague and incomplete [25]. As this nature of banking services makes them difficult to access, clients rely more on reputation, considering it a strategic signal that reflects the overall quality of business actions [26] and provides clients with the information about future behavior and expectations. Banks' reputation can be defined as a perception of clients that the bank is credible, reliable, responsible, and worthy of their trust [27].

Researchers, as well as practitioners, recognize that reputation is particularly relevant for banks, having an especially important strategic role that helps banks protect their product portfolio, retain and attract clients, differentiate on the market, but also provide systemic value $[3,25,26,28]$. 
In general, a good reputation leads to higher financial performance and strategic advantage, reduces operating costs, stimulates loyalty and word of mouth, translates into permanent relationships, and attracts or retains qualified employees $[5,26,29,30]$. Research among banks indicates a positive relationship between reputation and banks' financial/accounting performance $[3,28]$ and a negative relation to leverage and riskiness profiles [3]. Moreover, reputation also has a significant influence on clients purchasing and repurchasing decisions [25], as well as on bank clients' loyalty and their willingness to make comments or positive recommendations [6].

According to Fombrun [31], reputation can be seen as a result of one's economic value (reputation capital), image (representation), and quality. Neef [32] lists four basic categories leading to reputation—corporate governance, environmental protection, employee rights, and product safety. Grgić [33] emphasizes that reputation encompasses a larger set of criteria, including financial indicators, quality of products and services, employee relations, role within the community, environmental protection, and business ethics. The most common antecedents proposed in the literature on corporate reputation is the quality of products/services [34], although previous research, e.g., [26] shows the importance of reliability and financial strength over product quality in times of crisis. Besides, recent research also recognized corporate social responsibility as an important predictor of bank reputation, e.g., [3].

In bank settings, previous research has, in general, recognized that the quality of products and services can be seen as one of the key antecedents of bank reputation, e.g., [25,30,35,36]. Without high-quality products and services, it is not possible to build a long-term sustainable reputation [37]. Due to the technological advances in banking, the characteristics of technology-driven banking solutions, such as internet banking and m-banking, has become one of the main drivers of the banks' reputation [13].

\subsection{Quality of m-Banking}

Jun and Palacios [14] emphasize that the development of electronic communication and channels have brought drastic changes to the bank sector's service environment, introducing multi-channel that encompass offline and online communication. Consequently, traditional banking is transforming into the direction of dislocated communications and direct transactions. At the same time, physical interaction between bank employees and clients becomes less important [38].

M-banking has become one of the key forms of virtual banking [39] and is considered as a "new radical innovation in the excellence of service delivery to banks" [40] (p. 2). By integrating mobile communication technology and banking financial services, m-banking has become an increasingly flexible service [41], providing time optimization, independence, convenience, prompt response to clients, decrease in operating costs and efficiency for banking transactions [9,12,42-44].

Still, it is important to note that the introduction of m-banking technology is not without risk. Laukkanen [12] notes that technological innovations, which require fast learning from the clients and are not sufficiently supported by the relevant information, could discourage clients in its adoption. Ha et al. [19] emphasize that client adoption of new technologies, such as m-banking, should consider the estimated cost, risk, benefits, and compliance. Besides, one of the critical elements determining the success of $\mathrm{m}$-banking service is the perceived provider's m-banking service quality [14]. The quality of the m-banking service can be defined as the perception of the bank's clients that the mobile banking system is capable of providing a service that will highly meet their needs and expectations [45].

Numerous researchers provide and investigate the main drivers of the bank's service quality. Two groups of research on the bank's quality are observed, depending on the delivery channels: Traditional (face-to-face) and technology-based channels.

Traditional banking channels have been extensively researched. One of the first studies was conducted by Mersha and Adlakha [46], who provided basic characteristics of good quality related to retail banking. Most of these researchers have been focused on the usage of SERVQUAL as the assessment tool for the overall service and product quality in banks. For example, Culiber and Rojšek [47] stress the importance of assurance, empathy, reliability, responsiveness, access, and tangibles. Arasli et al. [11] emphasize the assurance, while Choudhury [48] emphasize reliability, as the main 
dimension influencing service quality. Therefore, various researchers using SERVQUAL came to different conclusions concerning the most important service dimensions, depending on the context, i.e., the cultural environment of the banking system itself [49].

Recently, researchers, e.g., [14] have realized that dimension related to traditional offline banking services cannot be applied to the modern banking environment and conducted a substantial effort to develop such a framework for internet-banking. In that sense, most of the studies related to service quality of technology-based services are about online (internet-based) service quality, e.g., [16,17]. There were, however, several attempts to identify key determinants of $m$-banking service performance and quality. Nisha [50] identifies reliability, privacy, information quality, responsiveness, and empathy as important elements that affect clients' perceptions of the performance of $\mathrm{m}$-banking services. Asfour and Haddad [22] stress reliability, flexibility, privacy, accessibility, ease of navigation, efficiency, safety, as important dimensions, where privacy and accessibility were found to be the most influential comparing to the rest of the $\mathrm{m}$-banking dimensions. Malviya [51] asserts dimensions of assurance, safety, efficiency, convenience, reliability, responsiveness, and satisfaction while Jun and Palacios [14] provide the most comprehensive list of 17 dimensions of m-banking service quality grouped into two categories, namely m-banking application quality and m-banking client service quality. Furthermore, their study revealed $\mathrm{m}$-banking service quality dimensions of accuracy, mobile convenience, ease of use, diverse $\mathrm{m}$-banking services, and features, and continuous improvement, to have strong impacts on client satisfaction.

Research suggests safety and risk issues related to m-banking have been recognized as one of the major concerns of all the clients $[40,43]$. Moreover, ease of use, simplicity, and different features and products offered have a positive influence on perceived value [43,52].

The security of the mobile banking service is crucial for users, and the perception of risk and safety becomes an important feature affecting quality [52]. Techniques that threaten the security of m-banking today have historically been focused on personal computers. Clients want to know their application is safe, stable, and that all its functionalities are done accurately and on time. Concerns about safety can be seen as one of the most often barriers to the adoption of modern technologically driven bank solutions, e.g., [42,53-56].

Simplicity and ease of use are important as they ensure that the time and effort required to manage finances are kept to a minimum. Namely, simplicity primarily implies the perceived complexity of navigation [57] and potential user's / client's perception of how much effort the selected application will require [58]. It represents an individual response to a technological solution and an important prerequisite for the adoption of innovative technological solutions and perception of its quality [23].

The development of technology and various innovations have led to the creation of an affirmative climate for the placement of m-banking, providing customers with greater availability, convenience, and control of their finances and different financial products [59]. Once the appropriate infrastructure is in place, $\mathrm{m}$ - banking has the potential to increase the involvement of social segments of the financial market that have so far been excluded. With the advent of $\mathrm{m}$ - banking, the availability of credit and the possibility of investing are growing. In addition to the availability of financial services, an important feature of the adoption of m-banking and perception of its quality is the availability of support systems and personalized communication.

Based on the described research, m-banking services need to provide safety and reflect trustworthiness, as well as to be simple to us and, provide diverse services accurately with high speed. All of these commonly found dimensions are reflecting the unique nature of m-banking, such as ubiquity and mobility [14]. Consequently, these elements can be considered as crucial and important in providing high-quality $\mathrm{m}$-banking service and will be further evaluated.

\section{Research Model and Hypothesis Development}

M-banking presents an emerging strategic orientation of banks, and its role in bank reputation needs to be further examined [13]. Moreover, since the previous research indicated that there is no consensus 
of what constitutes the m-banking quality, by this research, we aim to provide a deeper understanding of specific dimensions of $m$-banking quality, and its impact on the bank reputation. Aiming to integrate the various approaches to $\mathrm{m}$-banking quality and the most common features of $\mathrm{m}$-banking quality that are emphasized as the most important ones in the current literature [22,40,43,50-52], we define the following dimensions of $m$-banking quality: Safety, simplicity, and variability. As previous literature suggests, banks need to consider how to use mobile banking services easily, to be safe, and provide a variety of services accurately and with high speed [60]. Furthermore, we propose to test the impact of perceived m-banking quality on the bank reputation. The research model is presented in Figure 1, while the support for different hypotheses is provided in the next sections.

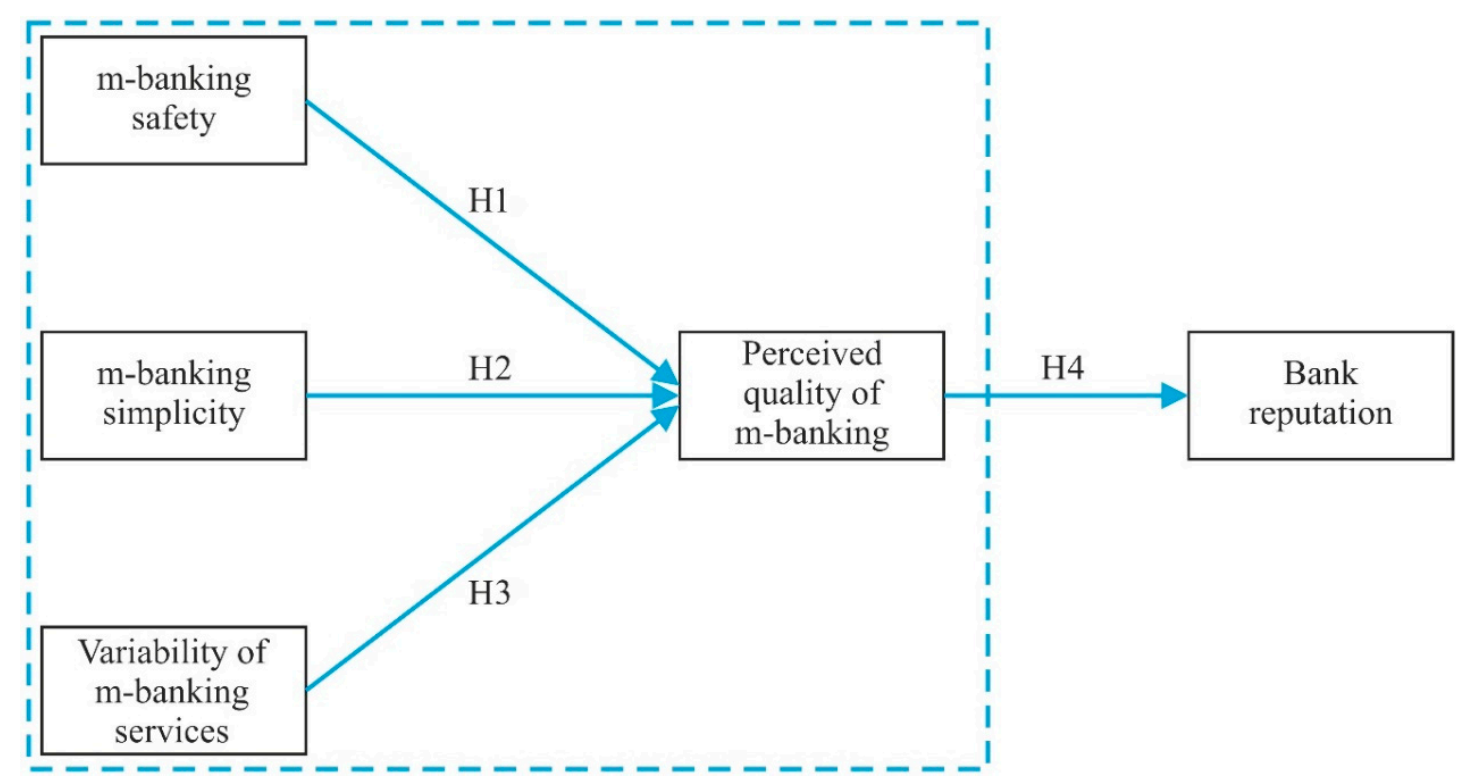

Figure 1. Research model.

\section{1. $m$-Banking Safety}

Previous empirical results indicate that client satisfaction increases when they perceive the bank transactions as safe [11], indicating that the safety of bank service is connected with clients' trust, and, finally, a bank reputation [53]. The safety of m-banking is defined as the ability to prevent unauthorized access to information and resources in user accounts, while at the same time allowing customer that the application is stable and that all functionalities of the application are done accurately and on time $[23,25]$. Concerns about perceived risk and safety seem to be one of the major barriers when it comes to m-banking adoption, e.g., [42,54-56]. Higher risk perception and fear of losses can make people avoid m-banking adoption [44] and question its quality. Safety has been proved as one of the most important determinants for $\mathrm{m}$-banking adoption among generation $\mathrm{Y}$ [61]. Clients can easily turn to other bank channels to execute payment and banking services if they have concerns related to $\mathrm{m}$-banking safety and payment technology [41]. As some previous research indicates, safety can be considered an important dimension of m-banking service quality, e.g., [22,51]. To test the effects of safety on m-banking service quality, we propose our first hypothesis:

Hypothesis 1 (H1). The safety of m-banking service has a positive effect on the perceived quality of mbanking service.

\section{2. m-Banking Simplicity}

Simplicity could be defined as the perceived ease of use and complexity of navigation through the application [57]. Previous research, e.g., [60] suggests that banks need to consider how to design 
their m-banking service to be simple and easy to use. It has been found that simplicity has a positive influence on the perceived value of m-banking services [43], as well as on its actual usage, e.g., [42,43]. When clients perceive that m-banking is easy to learn, with a friendly interface and real-time help, they will have a higher sense of self-efficacy, leading to higher creation of positive image and satisfaction with $\mathrm{m}$-banking [62]. Clients can consider $\mathrm{m}$-banking services less appealing as opposed to traditional services because m-banking services seek more mental effort, are time-consuming, or creating frustration [41]. To test the effects of perceived simplicity of m-banking service, we propose the following hypothesis:

Hypothesis 2 (H2). The simplicity of m-banking service has a positive effect on the perceived quality of mbanking service.

\subsection{Variability of m-Banking serVices}

For m-banking, a wide array of services available to clients through m-banking services become increasingly important. M-banking, in its simplest form, can provide the provision of support for simple banking transactions (e.g., bill payments) but also more complex services, such as arranging savings and investments and contracting additional services, such as insurance contracts. Variability of services over m-banking includes, thus, the availability of different financial services, with the highest level of variability of $\mathrm{m}$-banking services present in those systems that enable the provision of personalized services, as well as personalized marketing messages [23]. Previous research shows that broader variety and features can be seen as significant antecedents of quality, e.g., [25] and that content and quality of available service is important for mobile service quality [52]. In line with previous findings, we propose the following hypothesis:

Hypothesis 3 (H3). A variety of m-banking services has a positive effect on the perceived quality of mbanking services.

\subsection{Perceived Quality of m-Banking Services and Bank Reputation}

Although reputation is a multidimensional construct that differs according to different stakeholders [24], the quality of products and services has been recognized as one of the key antecedents of bank reputation, e.g., [25,30,35,36]. Ennew and Sekhon [37] argue that reputation is developing when services are accompanied by knowledge, expertise, consistency, and shared values, and without the high quality of products and services, it is not possible to build a viable long-term reputation. Through the quality of products and services, organizations show their credibility and get the trust of their stakeholders [5], increase client satisfaction, which leads to a high level of client commitment and loyalty [63]. Ruiz et al. [26] stress that the connection between the perceived quality of services and reputation is important as clients, to assess the perceived risk, rely on a bank reputation when objective and measurable attributes are not present. Bontis et al. [64], Grgić [33], and Wang et al. [25] in their research on the banking sector show that service quality leads to superior bank reputation. In the case of m-banking, m-banking service quality is expected to be a significant factor of bank reputation [51], and to test this relation, we propose the following hypothesis

Hypothesis 4 (H4). Perceived quality of m-banking service has a positive effect on bank reputation.

\section{Methodology}

\subsection{Research Instrument and Data Collection}

To test our research model and hypothesis, survey research was conducted to collect the responses from bank clients that use m-banking services of major banks in Croatia. The research instrument 
consists of four parts. The first part of the instrument measured m-banking service characteristics, and it consisted of 18 statements related to safety, simplicity, and variability of services of m-banking. The second part is comprised of five statements measuring the perceived quality of m-banking, while the third part consisted of six statements measuring bank reputation. The aforementioned statements were adapted from previously developed work by Wang et al. [25] and Ponzi et al. [27], which measured these dimensions in the context of internet banking. As both m-banking and internet banking services are technology-based channels, the measures were adjusted to reflect the m-banking instead of internet banking services. The last part of the instrument was related to respondents' data, including the frequency of $\mathrm{m}$-banking usage. All multi-item measures used were based on five-point Likert scales from 1 (strongly disagree) to 5 (strongly agree) and are shown in more detail in Table 1.

Table 1. Research instrument description.

\begin{tabular}{|c|c|c|c|}
\hline \multicolumn{2}{|c|}{ Construct } & $\begin{array}{l}\text { Code } \\
\text { S1 } \\
\text { S2 } \\
\text { S3 } \\
\text { S4 } \\
\text { S5 }\end{array}$ & Item \\
\hline \multirow[t]{2}{*}{$\begin{array}{l}\text { m-banking } \\
\text { characteristics }\end{array}$} & $\begin{array}{l}\text { Simplicity of } \\
\text { m-banking }\end{array}$ & $\begin{array}{l}\text { M1 } \\
\text { M2 } \\
\text { M3 } \\
\text { M5 } \\
\text { M5 }\end{array}$ & $\begin{array}{l}\text { Download and loading of } \mathrm{m} \text {-banking application is simple } \\
\text { Activation of } \mathrm{m} \text {-banking application is simple } \\
\text { Search within the } \mathrm{m} \text {-banking application is simple } \\
\text { Carry out of payments in the } \mathrm{m} \text {-banking application is simple } \\
\text { Contacting bank staff through the } \mathrm{m} \text {-banking application is simple }\end{array}$ \\
\hline & $\begin{array}{l}\text { Variability of } \\
\text { services over } \\
\text { m-banking }\end{array}$ & $\begin{array}{l}\text { V1 } \\
\text { V2 } \\
\text { V3 } \\
\text { V4 } \\
\text { V5 } \\
\text { V6 }\end{array}$ & $\begin{array}{l}\text { The application allows contracting deposit products } \\
\text { The application allows contracting and/or filling out credit application requirements } \\
\text { The application allows the purchase of shares in funds } \\
\text { The application allows contracting insurance policies } \\
\text { The application allows you to sign up for a card } \\
\text { The application allows personalized communication }\end{array}$ \\
\hline \multicolumn{2}{|c|}{ Bank reputation } & $\begin{array}{l}\text { R1 } \\
\text { R2 } \\
\text { R3 } \\
\text { R4 } \\
\text { R5 } \\
\text { R6 } \\
\text { R7 }\end{array}$ & $\begin{array}{c}\text { I have a good feeling regarding my bank } \\
\text { I trust my bank } \\
\text { I respect my bank } \\
\text { My bank has a tradition } \\
\text { My bank has the strength of an international organization } \\
\text { My bank appreciates me as a client } \\
\text { Bank has overall a good reputation }\end{array}$ \\
\hline
\end{tabular}

Source: Authors' work based on Wang et al. [25] and Ponzi et al. [27].

Bank's volume of assets was a criterion used for the selection of financial institutions, as used in previous studies, e.g., [26]. The selection of respondents was deliberate, corresponding to age and gender of the population structure of the Republic of Croatia available from the last census. The questionnaire was sent to selected respondents via electronic mail on a sample of 500 clients of five major Croatian banks. In total, among 25 banks in Croatia, these banks control up to $70 \%$ of assets on the market and are responsible for about $75 \%$ of all bank loans. As of their size and importance, they were also the first to provide modern technology-based channels for offering their products and service, and thus their clients were chosen to participate in this study. Each of the respondents received an e-mail invitation to participate in the study, with a brief explanation of the study research goal and objectives. Respondents' anonymity was fully secured. During data collection, it was checked whether the data followed the planned quota design of the sample. After the data collection, the preparation and verification of the data collected by the survey were done by tests aimed at examining atypical values in the data and examining assumptions about the normal distribution of manifest variables.

In total, 154 responses were received. The sample consisted of $53 \%$ women, and with $79.8 \%$ of respondents with a university or higher level of education degree. Among respondents, $26.6 \%$ of them 
use m-banking several times a week, $20.1 \%$ of respondents use m-banking every day, while $13.6 \%$ of them use it less than once a month. The distribution of m-banking usage is presented in Table 2.

Table 2. Frequency of m-banking usage.

\begin{tabular}{ccc}
\hline & Frequency & \% \\
\hline Every day & 31 & 20.1 \\
Several times a week & 41 & 26.6 \\
Once a week & 20 & 12.9 \\
Several times a month & 38 & 24.7 \\
Once a month & 3 & 1.9 \\
Less than once a month & 21 & 13.6 \\
Total & 154 & 100 \\
\hline
\end{tabular}

\subsection{Statistical Analysis}

Several statistical methods and analyses were done to ensure research validity and reliability, as well as to test our hypotheses.

Primarily, research instrument validity was checked. As the questionnaire items were adapted from the existing literature, and a pilot study was done, a content validity has been ensured. By using explanatory factor analysis to uncover the underlying structure of a relatively large set of variables, which were used under the a priori assumption that any indicator may be associated with any factor [65], convergent validity was done. By using confirmatory factor analysis, we tested for discriminate validity, to determine the degree to which measures of different latent variables are unique enough to be easily differentiated from other constructs [66].

Secondly, using Cronbach's alpha coefficients allowed for reliability analysis that was done to ensure the internal consistency of the items used for calculating scales [67].

Thirdly, to test for possible data validity problems indicated by negative or low correlations [68], our research data were analyzed using descriptive and non-parametric correlation statistics.

Fourthly, using the fit indices Chi-square index, Non-normed-fit index (NNFI), Comparative-fit index (CFI), and Root-mean-square-error (RMSEA) proposed by Hooper et al. [69], structural equations model (SEM) fit was tested.

Finally, SEM was used for testing our hypotheses with the special attention on the signs and statistical significance of the parameters and the amount of variance of endogenous constructs accounted for by independent constructs.

\section{Results}

\subsection{Validity and Reliability Analysis}

As the first step in data analysis, validity analysis was done to check the validity of the research instrument used. More specifically, we checked for content validity, convergent validity, and discriminant validity. Content validity was attained by using items from the existing literature, but also through preliminary research that was done on a sample of several randomly selected users of $\mathrm{m}$-banking to test if questionnaire items are clear and if an appropriate level of understanding and interpretation of questionnaire items can be expected.

By using the statistical package SPSS v.23, the explanatory factor analysis was done to investigate the convergent validity. Iterated principal axis factor was combined with varimax rotation extracted five factors, as presented in Table 3. 
Table 3. Rotated factor matrix for five factors.

\begin{tabular}{|c|c|c|c|c|c|c|}
\hline \multirow{2}{*}{ Dimension } & \multirow{2}{*}{ Item } & \multicolumn{5}{|c|}{ Factor } \\
\hline & & 1 & 2 & 3 & 4 & 5 \\
\hline \multirow{5}{*}{ Safety of m-banking } & S1 & 0.815 & & & & \\
\hline & S2 & 0.772 & & & & \\
\hline & S3 & 0.747 & & & & \\
\hline & S4 & 0.699 & & & & \\
\hline & S5 & 0.702 & & & & \\
\hline \multirow{5}{*}{ Simplicity of m-banking } & M1 & & 0.727 & & & \\
\hline & M2 & & 0.709 & & & \\
\hline & M3 & & 0.864 & & & \\
\hline & M4 & & 0.873 & & & \\
\hline & M5 & & 0.859 & & & \\
\hline \multirow{6}{*}{ Variability of services over m-banking } & V1 & & & 0.770 & & \\
\hline & $\mathrm{V} 2$ & & & 0.892 & & \\
\hline & $\mathrm{V} 3$ & & & 0.713 & & \\
\hline & $\mathrm{V} 4$ & & & 0.886 & & \\
\hline & V5 & & & 0.883 & & \\
\hline & V6 & & & 0.739 & & \\
\hline \multirow{5}{*}{ Perceived quality of m-banking } & Q1 & & & & 0.644 & \\
\hline & Q2 & & & & 0.647 & \\
\hline & Q3 & & & & 0.746 & \\
\hline & $\mathrm{Q} 4$ & & & & 0.689 & \\
\hline & Q5 & & & & 0.748 & \\
\hline \multirow{7}{*}{ Bank reputation } & R1 & & & & & 0.837 \\
\hline & $\mathrm{R} 2$ & & & & & 0.851 \\
\hline & R3 & & & & & 0.841 \\
\hline & $\mathrm{R} 4$ & & & & & 0.687 \\
\hline & R5 & & & & & 0.736 \\
\hline & R6 & & & & & 0.827 \\
\hline & R7 & & & & & 0.843 \\
\hline
\end{tabular}

Costello and Osborne [66] suggested applying a loading cut-off value in the magnitude from 0.40 to 0.60 . According to the defined criteria, all of the measurement factors were to be retained. Our factor analysis confirmed the existence of five factors.

By applying a confirmatory factor analysis, discriminant validity was assessed. Factor loadings, together with $t$-values, are presented in Table 4. According to Costello and Osborne [66], all $\lambda$ 's should be higher than the cut-off value of 0.50 , and all of the $t$-values should exceed 1.96. Our data indicated a statistical significance of the observed loading paths.

Table 4 also presents data regarding Cronbach's alpha coefficients that were calculated for the reliability analysis. As internal consistency coefficients of 0.70 or higher are considered to indicate adequate reliability [67], and as all Cronbach's alpha coefficients of items analyzed were above the cut-off value, we can conclude item scales used show internally consistency. 
Table 4. Standardized loading estimates and $t$-values, Cronbach's alpha.

\begin{tabular}{|c|c|c|c|c|c|c|}
\hline Varibale & Item & $\begin{array}{l}\text { Standardized } \\
\text { Factor Loading }\end{array}$ & $t$-Values & $p$-Value & $\mathbf{R} 2$ & $\begin{array}{c}\text { Cronbach's } \\
\text { Alpha }\end{array}$ \\
\hline \multirow{5}{*}{$\begin{array}{c}\text { Safety of } \\
\text { m-banking }\end{array}$} & S1 & 0.889 & 37.113 & 0.000 & 0.791 & \multirow{5}{*}{0.927} \\
\hline & S2 & 0.919 & 41.477 & 0.000 & 0.845 & \\
\hline & S3 & 0.769 & 13.314 & 0.000 & 0.592 & \\
\hline & $\mathrm{S} 4$ & 0.790 & 16.068 & 0.000 & 0.624 & \\
\hline & S5 & 0.869 & 25.475 & 0.000 & 0.755 & \\
\hline \multirow{5}{*}{$\begin{array}{l}\text { Simplicity of } \\
\text { m-banking }\end{array}$} & M1 & 0.791 & 13.579 & 0.000 & 0.625 & \multirow{5}{*}{0.932} \\
\hline & M2 & 0.750 & 13.048 & 0.000 & 0.563 & \\
\hline & M3 & 0.888 & 22.398 & 0.000 & 0.788 & \\
\hline & M4 & 0.905 & 38.320 & 0.000 & 0.820 & \\
\hline & M5 & 0.936 & 53.281 & 0.000 & 0.876 & \\
\hline \multirow{6}{*}{$\begin{array}{l}\text { Variability of } \\
\text { services over } \\
\text { m-banking }\end{array}$} & $\mathrm{V} 1$ & 0.694 & 9.822 & 0.000 & 0.482 & \multirow{6}{*}{0.887} \\
\hline & $\mathrm{V} 2$ & 0.912 & 32.366 & 0.000 & 0.831 & \\
\hline & V3 & 0.630 & 8.118 & 0.000 & 0.397 & \\
\hline & V4 & 0.901 & 27.473 & 0.000 & 0.811 & \\
\hline & V5 & 0.876 & 18.999 & 0.000 & 0.768 & \\
\hline & V6 & 0.736 & 11.665 & 0.000 & 0.541 & \\
\hline \multirow{5}{*}{$\begin{array}{l}\text { Perceived } \\
\text { quality of } \\
\text { m-banking }\end{array}$} & Q1 & 0.891 & 35.602 & 0.000 & 0.793 & \multirow{5}{*}{0.965} \\
\hline & Q2 & 0.889 & 27.831 & 0.000 & 0.790 & \\
\hline & Q3 & 0.933 & 69.254 & 0.000 & 0.870 & \\
\hline & $\widehat{\mathrm{Q}} 4$ & 0.935 & 43.711 & 0.000 & 0.874 & \\
\hline & Q5 & 0.952 & 73.597 & 0.000 & 0.906 & \\
\hline \multirow{6}{*}{$\begin{array}{c}\text { Bank } \\
\text { reputation }\end{array}$} & R1 & 0.875 & 21.966 & 0.000 & 0.766 & \multirow{6}{*}{0.938} \\
\hline & $\mathrm{R} 2$ & 0.913 & 19.664 & 0.000 & 0.834 & \\
\hline & $\mathrm{R} 3$ & 0.895 & 30.084 & 0.000 & 0.801 & \\
\hline & $\mathrm{R} 4$ & 0.705 & 10.209 & 0.000 & 0.497 & \\
\hline & R5 & 0.721 & 10.837 & 0.000 & 0.520 & \\
\hline & R6 & 0.827 & 19.585 & 0.000 & 0.685 & \\
\hline
\end{tabular}

\subsection{Correlation Analysis}

A non-parametric correlation analysis was done to assess the nature of the connection among analyzed variables. Spearman's correlation coefficients have revealed several very low (near-zero) correlations between some of the examined items (see Tables 5 and 6). However, most coefficients showed that there was a medium to low correlation between items related to the dimension of m-banking service quality, perceived quality, and reputation.

The results, although moderately, emphasize the connection between examined items, which indicates a positive connection between different dimensions, quality, and reputation. 
Table 5. Descriptive statistics and correlation coefficients for the dimensions Safety of m-banking, Simplicity of m-banking, and Variability of services over m-banking.

\begin{tabular}{|c|c|c|c|c|c|c|c|c|c|c|c|c|c|c|c|c|c|c|}
\hline Variable & Mean & Std. Dev. & S1 & S2 & S3 & S4 & S6 & M1 & M2 & M3 & M4 & M5 & V1 & V2 & V3 & V4 & V5 & V6 \\
\hline S1 & 5.15 & 1.57 & 1 & $0.848^{* *}$ & $0.671^{* *}$ & $0.629 * *$ & $0.800 * *$ & $0.538 * *$ & 0.470 ** & 0.433 ** & 0.476 ** & $0.538^{* *}$ & $0.212 * *$ & 0.132 & 0.258 ** & $0.163 *$ & 0.146 & 0.348 ** \\
\hline S2 & 5.27 & 1.54 & & 1 & 0.703 ** & $0.720 * *$ & $0.767^{* *}$ & $0.590^{* *}$ & $0.529 * *$ & $0.505^{* *}$ & 0.562 ** & $0.593 * *$ & $0.178^{*}$ & $0.164^{*}$ & $0.203^{*}$ & 0.158 * & 0.104 & 0.276 ** \\
\hline S3 & 5.21 & 1.57 & & & 1 & $0.707^{* *}$ & 0.636 ** & $0.481^{* *}$ & 0.412 ** & $0.428 * *$ & $0.426^{* *}$ & $0.517^{* *}$ & 0.141 & 0.073 & $0.212 * *$ & 0.118 & 0.071 & $0.225^{* *}$ \\
\hline S4 & 5.56 & 1.43 & & & & 1 & 0.712 ** & $0.552 * *$ & 0.422 ** & $0.497 * *$ & $0.456^{* *}$ & $0.510^{* *}$ & 0.106 & 0.148 & $0.175^{*}$ & 0.110 & 0.070 & 0.184 * \\
\hline S6 & 5.32 & 1.58 & & & & & 1 & $0.596^{* *}$ & 0.540 ** & $0.535^{* *}$ & $0.528^{* *}$ & $0.631^{* *}$ & $0.219^{* *}$ & 0.203 * & $0.313^{* *}$ & 0.204 * & $0.196 *$ & $0.363^{* *}$ \\
\hline M1 & 5.79 & 1.48 & & & & & & 1 & 0.688 ** & $0.737 * *$ & $0.688^{* *}$ & $0.721 * *$ & $0.208^{* *}$ & 0.162 * & 0.183 * & $0.166^{*}$ & 0.085 & 0.225 ** \\
\hline M2 & 5.47 & 1.57 & & & & & & & 1 & $0.704 * *$ & $0.635^{* *}$ & $0.689 * *$ & $0.265 * *$ & $0.217^{* *}$ & $0.211 * *$ & 0.212 ** & 0.158 & 0.322 ** \\
\hline M3 & 5.68 & 1.51 & & & & & & & & 1 & 0.803 ** & $0.818^{* *}$ & $0.220 * *$ & 0.232 ** & $0.182^{*}$ & 0.240 ** & $0.211^{* *}$ & 0.264 ** \\
\hline M4 & 5.73 & 1.44 & & & & & & & & & 1 & $0.865^{* *}$ & $0.221 * *$ & 0.232 ** & $0.204^{*}$ & $0.199 *$ & $0.172 *$ & $0.290 * *$ \\
\hline M5 & 5.81 & 1.45 & & & & & & & & & & 1 & $0.223 * *$ & 0.211 ** & $0.275^{* *}$ & $0.217^{* *}$ & $0.169 *$ & $0.304^{* *}$ \\
\hline V1 & 3.88 & 2.00 & & & & & & & & & & & 1 & 0.667 ** & $0.657^{* *}$ & $0.589 * *$ & $0.563^{* *}$ & 0.246 ** \\
\hline V3 & 4.10 & 2.05 & & & & & & & & & & & & & 1 & $0.547^{* *}$ & $0.577^{* *}$ & 0.387 ** \\
\hline V4 & 3.38 & 2.00 & & & & & & & & & & & & & & 1 & $0.806 * *$ & $0.457 * *$ \\
\hline V5 & 3.55 & 2.01 & & & & & & & & & & & & & & & 1 & $0.405^{* *}$ \\
\hline V6 & 3.90 & 1.92 & & & & & & & & & & & & & & & & 1 \\
\hline
\end{tabular}

Note: ${ }^{* *}$ statistically significant at $1 \% ;{ }^{*} 5 \%$.

Table 6. Descriptive statistics and correlation coefficients for the dimensions Perceived quality of m-banking and Bank reputation.

\begin{tabular}{|c|c|c|c|c|c|c|c|c|c|c|c|c|c|c|}
\hline Variable & Mean & Std. Dev. & Q1 & Q2 & Q3 & Q4 & Q5 & R1 & $\mathbf{R} 2$ & R3 & R4 & R5 & R6 & R7 \\
\hline Q1 & 5.30 & 1.43 & 1 & $0.849 * *$ & $0.820^{* *}$ & $0.802^{* *}$ & $0.846^{* *}$ & $0.517^{* *}$ & $0.529^{* *}$ & $0.474^{* *}$ & $0.485^{* *}$ & $0.456^{* *}$ & $0.434^{* *}$ & 0.482 ** \\
\hline Q2 & 5.39 & 1.47 & & 1 & $0.837^{* *}$ & $0.824^{* *}$ & $0.821 * *$ & $0.587^{* *}$ & $0.613^{* *}$ & $0.528^{* *}$ & $0.557^{* *}$ & $0.514^{* *}$ & $0.494^{* *}$ & $0.542 * *$ \\
\hline Q3 & 5.34 & 1.55 & & & 1 & $0.876^{* *}$ & $0.902 * *$ & $0.458^{* *}$ & $0.516^{* *}$ & $0.398^{* *}$ & $0.443^{* *}$ & $0.491^{* *}$ & $0.368^{* *}$ & $0.458^{* *}$ \\
\hline Q4 & 5.40 & 1.41 & & & & 1 & $0.892 * *$ & $0.562 * *$ & $0.603^{* *}$ & $0.469 * *$ & 0.492 ** & $0.523^{* *}$ & $0.434^{* *}$ & $0.506^{* *}$ \\
\hline Q5 & 5.37 & 1.55 & & & & & 1 & $0.485^{* *}$ & $0.509^{* *}$ & $0.402^{* *}$ & $0.458^{* *}$ & $0.488^{* *}$ & $0.382^{* *}$ & 0.462 ** \\
\hline$\widehat{\mathrm{R}} 1$ & 5.00 & 1.67 & & & & & & 1 & $0.818^{* *}$ & $0.768^{* *}$ & $0.642^{* *}$ & $0.640^{* *}$ & $0.708^{* *}$ & $0.713^{* *}$ \\
\hline $\mathrm{R} 2$ & 4.94 & 1.78 & & & & & & & 1 & $0.865^{* *}$ & $0.646^{* *}$ & $0.611^{* *}$ & $0.728^{* *}$ & $0.704^{* *}$ \\
\hline $\mathrm{R} 3$ & 4.82 & 1.74 & & & & & & & & 1 & $0.603^{* *}$ & $0.585^{* *}$ & $0.747^{* *}$ & 0.740 ** \\
\hline $\mathrm{R} 4$ & 5.29 & 1.53 & & & & & & & & & 1 & $0.557^{* *}$ & $0.536^{* *}$ & $0.586^{* *}$ \\
\hline R5 & 5.03 & 1.71 & & & & & & & & & & 1 & $0.610^{* *}$ & 0.719 ** \\
\hline R6 & 4.82 & 1.81 & & & & & & & & & & & 1 & $0.797^{* *}$ \\
\hline R7 & 5.23 & 1.59 & & & & & & & & & & & & 1 \\
\hline
\end{tabular}




\subsection{Assessment of Model Fit}

Developing a structural equations model according to the proposed conceptual model was done by using the SAS module. It produced a chi-square of 658.034 with 343 degrees of freedom. Table 7 presents the indices used for assessing the overall model validity. Besides chi-square, other indices were additionally used to assess the overall model fit.

Table 7. Fit indices for the hypothesized model.

\begin{tabular}{ccc}
\hline Fitness Indicator & Model Estimated & Explanations \\
\hline Chi-square $\left(\chi^{2}\right)$ & 658.034 & $\chi^{2}$ is not significant \\
Degrees of freedom $(\mathrm{df})$ & 343 & \\
$p$-value & 0.000 & \\
$\chi^{2} / \mathrm{df}$ & 1.918 & Very good, close to 2 \\
NNFI & 0.897 & Good fit, $>0.8$ \\
CFI & 0.907 & Satisfactory fit, $>0.9$ \\
RMSEA & 0.077 & Acceptable fit, $<0.08$ \\
$90 \%$ confidence interval of RMSEA & $(0.068-0.086)$ & Upper limit $<0.10$, a good result \\
\hline
\end{tabular}

The values of the Non-Normed-fit index (NNFI), as well as the Comparative-fit index (CFI), were near the proposed value of 0.90 , which indicated a good fit. Root-mean-square-error (RMSEA) indicated results 0.077 which is acceptable e.g., [61]. In other words, we may conclude that our hypothesized model fulfilled the aforementioned requests.

\subsection{Hypothesis Testing}

As the overall model exhibited a good fit, we were able to further examine the model to assess if proposed theoretical relationships can be applied in a specific research context. The structural equation model was used for statistical testing of the hypothesis, the statistical significance of the parameters (measured by $t$-value), and the amount of variance of endogenous constructs accounted for by independent constructs (measured by the squared multiple correlation coefficient- $R^{2}$ ).

In Figure 2, the results of the path analysis are presented. As can be seen, the path coefficient for all the hypothesis was supported and with statistical significance present at the $1 \%$ level. Detailed results are presented in Table 8.

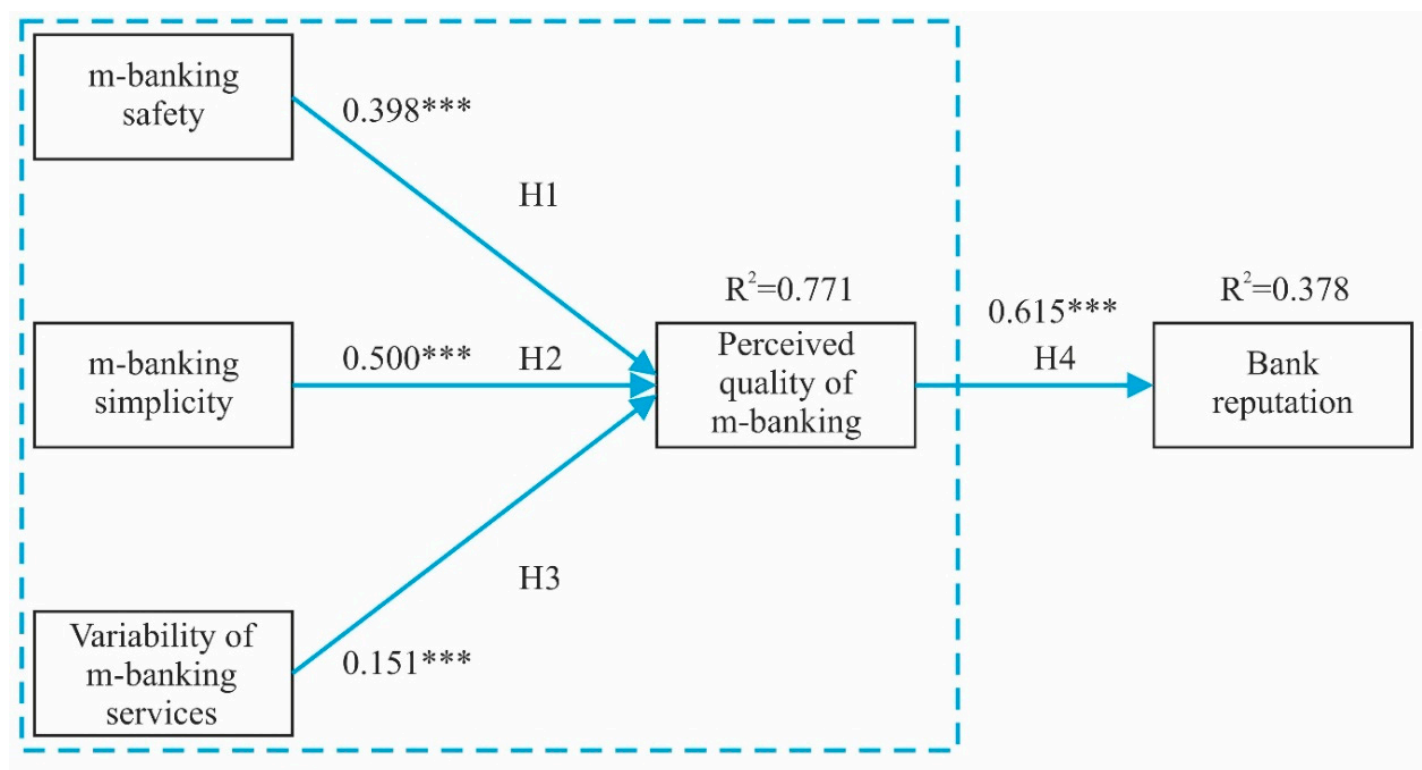

Note: $* * *$ significant $>$ at $1 \%$

Figure 2. Path Diagram with path coefficients estimates and their significance levels. 
Table 8. Direct effects of path coefficients.

\begin{tabular}{cccccc}
\hline Hypothesis & Path Coeffcient & Std. Error & Z-Value & $p$-Value & R-Squared \\
\hline safety $\rightarrow$ perceived quality & 0.398 & 0.123 & 3.235 & $0.001^{* * *}$ & \\
simplicity $\rightarrow$ perceived quality & 0.500 & 0.120 & 4.172 & $0.000^{* * *}$ & 0.771 \\
variability $\rightarrow$ perceived quality & 0.151 & 0.044 & 3.455 & $0.001^{* * *}$ & \\
perceived quality $\rightarrow$ reputation & 0.615 & 0.078 & 7.934 & $0.000^{* * *}$ & 0.378 \\
\hline
\end{tabular}

Note: ${ }^{* * *}$ statistically significant at $1 \%$.

\section{Discussion}

Given the influence of $\mathrm{m}$-banking, as well as possible effects of $\mathrm{m}$-banking service quality, the paper aimed to analyze the relation between $\mathrm{m}$-banking quality and bank reputation and to investigate elements of m-banking quality. With the emphasis on the application of relevant aspects of theory and practice and perception of $\mathrm{m}$-baking clients, the goal of the paper was to conceptualize the components of the quality of m-banking services, an aspect of research somehow neglected in the examination of m-banking [14]. Besides, the goal was to provide a better insight into their relationship with the reputation of banks. Applying the structural equation modeling method allowed us to investigate the direct and indirect determinants of banks' reputation.

Corporate reputation is an important intangible asset of a company that can be linked to the most important financial indicators and long-term sustainable competitive advantage of the company. Determining a bank's competitive position is no longer solely the result of traditional measures such as financial indicators (ROA, ROE, EBITDA) and/or market share, but also qualitative measures that can be linked to intangible assets as bank's reputation. In that sense, exploring elements leading to bank reputation can be seen as an important step in this new market positioning.

Confirming one of the most common assumptions on the impact of product quality on bank reputation [34] and in line with previous similar research e.g., [25,26,33,64], our study has validated that the perceived quality of $\mathrm{m}$-banking service has a positive effect on bank reputation. To differentiate on the market, banks have to take into account not only the development of modern technology-based services but also ensure their quality.

In line with previous research, e.g., [43,52], safety, ease of use, and variability of services offered have a positive influence on perceived quality, thus stressing the importance of these aspects in designing and providing the service of $\mathrm{m}$-banking. These elements can be considered important not only to retain an existing client but also to attract new ones [42].

Not only that, as literature reveals, but risk and safety are also major contributing factors for the slow uptake of mobile banking [43], as our research has shown, safety affects the perceived quality. Due to their reputation, banks make great efforts to maintain the security of their systems and invest in the development of security systems of the latest technology. User education, automation, and the legal framework can reduce the likelihood of abuse, but they cannot eliminate it. Thus, safety and low perception of risk need to be accompanied by m-banking service.

Due to the particular nature of m-banking, which requires a certain level of knowledge and skill, simplicity seen as the ease of use and navigation through the system also plays a crucial role in determining m-banking quality. In line with previous research, e.g., [60], ease of using financial management services has been proven as crucial in the process of defining and designing quality of $\mathrm{m}$-banking service. By maximizing interactivity and achieving ease of navigation, time and effort for financial management are kept to a minimum, thus, leading to a higher perception of quality. In this process, customer support can serve as support and have an educational element for customers.

If bank customers do not benefit from using m-banking services, consequently, they will leave this service, and banks will significantly decrease resources used to support it [42]. Thus, it is viable for banks to offer a variability of products in their m-banking service. In line with previous research, a broader variety and features, as well as the content of available service, can be seen as significant antecedents of m-banking quality, e.g., [25,52]. 


\section{Conclusions and Implications}

With an emphasis on the application of relevant aspects of theory and practice, the components of the quality of $\mathrm{m}$-banking services have been conceptualized, which enabled a better insight into their connection with the reputation of banks. Through the understanding of key measures and indicators of the quality of m-banking services, the cause-and-effect relations are pointed out, which enables the creation of active practices of connection with the reputation of banks by encouraging the development of the use of information and communication technologies. In this way, a set of activities can be designed that best suits the local conditions in which banks operate and making it possible to create a competitive advantage for banks. Through this research, this paper has oriented towards understanding the importance of m-banking service quality and its connection to reputation. Moreover, as of scarcity in the existing research, the paper also explored antecedents of m-banking quality. In this paper, the aim was to contribute to the current literature by identifying those aspects of $\mathrm{m}$-banking that are most likely to drive the growth of banks' reputation. We analyzed the responses of 154 users of m-banking services of five major banks in Croatia. Results show that all analyzed elements of m-banking quality, namely: Safety, simplicity, and variability of $\mathrm{m}$-banking services have a positive effect on the perceived quality of $\mathrm{m}$-banking service, thus confirming our first three hypotheses. In addition, it was hypothesized that the quality of m-banking service will be correlated with bank reputation, which this research has confirmed. Results reveal that the perceived quality of m-banking service has a positive effect on bank reputation, confirming our fourth hypothesis.

M-banking services, as one of the disruptive technologies that change the way of communication and business operations, are becoming increasingly widespread service, enabling us to have instant insight into the financial situation. Clients, on the other hand, are more informed about banks through different communication channels, they are more demanding and ask to have secure and instant bank service and banks are starting to exploit new digital opportunities moving to more agile technologies [70].

High-quality m-banking services (characterized by safety, simplicity, and variety) build trust towards the bank and, therefore, directly influence the bank's reputation, one of the bank's major strategic goals.

The implementation of information and communication technology through m-banking services demonstrates a movement from the traditional way of doing business towards the integration of information technology as an integral part of the bank's services. Consequently, banks offer their services through various channels and promote themselves on the global market. Still, as of specifics of bank services, the reputation of banks plays one of the crucial roles in clients' purchasing decisions, and it is an important element of bank differentiation strategies in various markets.

The results of the research can provide the basis for making recommendations concerning the use of information and communication technologies in the field of mobile communications, as an incentive for the growth of banks' reputation. Upon designing an m-banking services, organizations should emphasize and develop a service that is safe, easy to use but also offers a diverse set of possibilities. Understanding the key measures and quality indicators of $\mathrm{m}$-banking services highlights the cause-and-effect relationships that enable the creation of active marketing and organizational practices that can lead to client satisfaction. This can allow designing activities that are best suited for the local conditions in which banks operate and enables them to create their specific competitive advantage.

Given that reputation is a perception or a public image of a bank, it is not under the direct control and is, therefore, difficult to manipulate [71]. Banks, therefore, seek to defend and sustain their reputation, aiming to provide novel service with an adequate level of quality. The risk of reputation, or the likelihood of occurrence of circumstances causing loss of trust, is of great importance for each bank. Therefore, it must be supervised and managed [72-74].

There are certain limitations of the study that need to be emphasized. First, the research sample is relatively small and from a single-country study, capturing only customers of major banks in Croatia. Thus, the sample could be more extensive to get more generalized results. Similar studies in the future should be conducted on a larger and international sample of m-banking users. 
Second, a cross-sectional design was used in our study. Although this kind of research design is ideal for conducting descriptive analyses, we used it to test a causal model of the influence of m-banking quality on banks' reputation. Consequently, our research had to deal with the internal validity problem in establishing a cause-and-effect relationship without a time dimension. To resolve the issue of internal validity, future research activities should include a cohort analysis as a series of repeated cross-sectional studies. Such a design could be used to describe the aggregate change in m-banking quality and the bank's reputation over time. Besides, a longitudinal research design would enable us to test the causality determined in this study. It could also be effectively conducted by applying a multiple case study approach.

Future research should encompass a wider number of respondents and try to incorporate more objective measures to assess the quality of m-banking service, as well as reputation. Moreover, additional elements that can affect the perceived quality of $\mathrm{m}$-banking need to be incorporated. Overall bank reputation can be dependent on the quality of different products and services bank offers, so a deeper understanding of bank reputation needs to take a wider aspect, analyzing bank portfolio and reputation from the employee, client, supplier, and general pubic point of view.

Author Contributions: Conceptualization, M.A.O. and B.S.; methodology, M.P.B. and B.S.; validation, A.A., M.A.O. and S.S.; formal analysis, B.S.; data curation, B.S.; writing—original draft preparation, B.S., A.A. and S.S.; writing - review and editing, M.P.B.; visualization, M.P.B.; supervision, M.A.O. All authors have read and agreed to the published version of the manuscript.

Funding: This research received no external funding.

Conflicts of Interest: The authors declare no conflict of interest.

\section{References}

1. Barney, J.B.; Clark, D.N. Resource-Based Theory-Creating and Sustaining Competitive Advantage; Oxford University Press Inc.: New York, NY, USA, 2007.

2. Dierickx, I.; Cool, K. Asset stock accumulation and sustainability of competitive advantage. Manag. Sci. 1989, 35, 1504-1513. [CrossRef]

3. Dell'Atti, S.; Trotta, A.; Iannuzzi, A.P.; Demaria, F. Corporate social responsibility engagement as a determinant of bank reputation: An empirical analysis. Corp. Soc. Responsib. Environ. Manag. 2017, 24, 589-605. [CrossRef]

4. Ruiz, B.; García, J. Modelling customer-based bank reputation: The moderating role of uncertainty avoidance. Int. J. Bank Mark. 2019, 37, 340-361. [CrossRef]

5. Fombrun, C. Reputation: Realizing Value from the Corporate Image; Harvard Business School Press: Boston, MA, USA, 1996.

6. Ruiz, B.; Esteban, A.; Gutiérrez, S. Determinants of reputation of leading Spanish financial institutions among their customers in a context of economic crisis. BRQ Bus. Res. Q. 2014, 17, 259-278. [CrossRef]

7. Sanchez, J.L.F.; Luna, L. The creation of value through corporate reputation. J. Bus. Ethics 2007, 76, 335-346. [CrossRef]

8. Barrios, S.; Burgelman, J.C. Europe needs more Lisbon to make the ICT investments effective. Inter Econ. 2008, 43, 124-134. [CrossRef]

9. Afshan, S.; Sharif, A. Acceptance of mobile banking framework in Pakistan. Telemat. Inform. 2016, 33, 370-387. [CrossRef]

10. Reis, J.R.G.; Ferreira, F.A.F.; Monteiro Barata, J.M. Technological innovation in banking services: An exploratory analysis to perceptions of the front office employee. Prob. Perspect. Manag. 2013, 11, 34-49.

11. Arasli, H.; Katircioglu, S.T.; Mehtap-Smadi, S. A comparison of service quality in the banking industry: Some evidence from Turkish- and Greek-speaking areas in Cyprus. Int. J. Bank Mark. 2005, 23, 508-526. [CrossRef]

12. Laukkanen, T. Mobile banking. Int. J. Bank Mark. 2017, 35, 1042-1043. [CrossRef]

13. Calisir, F.; Gumussoy, C.A. Internet banking versus other banking channels: Young consumers' view. Int. J. Inf. Manag. 2008, 28, 215-221. [CrossRef]

14. Jun, M.; Palacios, S. Examining the key dimensions of mobile banking service quality: An exploratory study. Int. J. Bank Mark. 2016, 34, 307-326. [CrossRef] 
15. Ganguli, S.; Roy, S.K. Generic technology-based service quality dimensions in banking: Impact on customer satisfaction and loyalty. Int. J. Bank Mark. 2011, 29, 168-189. [CrossRef]

16. Jayawardhena, C. Measurement of service quality in internet banking: The development of an instrument. J. Mark. Manag. 2004, 20, 185-207. [CrossRef]

17. Rod, M.; Ashill, N.J.; Shao, J.; Carruthers, J. An examination of the relationship between service quality dimensions, overall internet banking service quality and customer satisfaction: A New Zealand study. Mark. Intell. Plan 2009, 27, 103-126. [CrossRef]

18. Akturan, U.; Tezcan, N. Mobile banking adoption of the youth market: Perceptions and intentions. Mark. Intell. Plan 2012, 30, 444-459. [CrossRef]

19. Ha, K.H.; Canedoli, A.; Baur, A.W.; Bick, M. Mobile banking-Insights on its increasing relevance and most common drivers of adoption. Electron. Mark. 2012, 22, 217-227. [CrossRef]

20. Zhou, T. Understanding users' initial trust in mobile banking: An elaboration likelihood perspective. Comput. Hum. Behav. 2012, 28, 1518-1525. [CrossRef]

21. Sagib, G.K.; Zapan, B. Bangladeshi mobile banking service quality and customer satisfaction and loyalty. Manag. Market. 2014, 9, 331-346.

22. Asfour, H.K.; Haddad, S.I. The impact of mobile banking on enhancing customers' e-satisfaction: An empirical study on commercial banks in Jordan. Int. Bus. Res. 2014, 7, 145-169. [CrossRef]

23. Staresinic, B. Povezanost Kvalitete Mobilnog Bankarstva i Reputacije Banaka. Ph.D. Thesis, Faculty of Economics and Business, University of Zagreb, Zagreb, Croatia, 2019.

24. Trotta, A.; Cavallaro, G. Measuring corporate reputation: A framework for Italian banks. Int. J. Econ. Financ. Stud. 2012, 4, 21-30.

25. Wang, Y.; Lo, H.P.; Hui, Y.V. The antecedents of service quality and product quality and their influences on bank reputation: Evidence from the banking industry in China. Manag. Serv. Qual. 2003, 13, 72-83. [CrossRef]

26. Ruiz, B.; García, J.A.; Revilla, A.J. Antecedents and consequences of bank reputation: A comparison of the United Kingdom and Spain. Int. Mark. Rev. 2016, 33, 781-805. [CrossRef]

27. Ponzi, L.J.; Fombrun, C.J.; Gardberg, N.A. RepTrak ${ }^{\mathrm{TM}}$ Pulse: Conceptualizing and validating a short-form measure of corporate reputation. Corp. Reput. Rev. 2011, 14, 15-35. [CrossRef]

28. Roberts, P.W.; Dowling, G.R. Corporate reputation and sustained superior financial performance. Strateg. Manag. J. 2002, 23, 1077-1093. [CrossRef]

29. Flatt, S.J.; Kowalczyk, S.J. Corporate reputation as a mediating variable between corporate culture and financial performance. In Proceedings of the 2006 Reputation Institute Conference, New York, NY, USA, 25-28 May 2006.

30. Krzakiewicz, K.; Cyfert, S. Organizational reputation risk management as a component of the dynamic capabilities management process. Manag. Sci. 2015, 19, 6-18. [CrossRef]

31. Fombrun, C.J. Corporate reputations as economic asset. In The Blackwell Handbook of Strategic Management; Hitt, M., Freeman, E.R., Harisson, S.J., Eds.; Blackwell Publishers: Oxford, UK, 2001; pp. $289-312$.

32. Neef, D. Managing Corporate Reputation and Risk; Routledge: New York, NY, USA, 2012.

33. Grgić, D. Indeks reputacije poduzeća: Empirijsko istraživanje u bankovnom sektoru. Market Rev. Mark. Theory Pract. 2012, 24, 23-45.

34. Barnett, M.L.; Jermier, J.M.; Lafferty, B.A. Corporate reputation: The definitional landscape. Corp. Reput. Rev. 2006, 9, 26-38. [CrossRef]

35. Rindova, V.P.; Williamson, I.O.; Petkova, A.P.; Sever, J.M. Being good or being known: An empirical examination of the dimensions, antecedents, and consequences of organizational reputation. Acad. Manag. J. 2005, 48, 1033-1049. [CrossRef]

36. Vitezić, N. Corporate reputation and social responsibility: An analysis of large companies in Croatia. Int. Bus. Econ. Res. J. 2011, 10, 85-96. [CrossRef]

37. Ennew, C.; Sekhon, H.S. Trust and Trustworthiness in Retail Financial Services; Routledge: London, UK, 2014.

38. Bitner, M.J.; Brown, S.W.; Meuter, M.L. Technology infusion in service encounters. J. Acad. Mark. Sci. 2000, 28, 138-149. [CrossRef]

39. Lin, H.F. An empirical investigation of mobile banking adoption: The effect of innovation attributes and knowledge-based trust. Int. J. Inf. Manag. 2011, 31, 252-260. [CrossRef] 
40. Dash, M.; Bhusan, P.B.; Samal, S. Determinants of customers' adoption of mobile banking: An empirical study by integrating diffusion of innovation with attitude. J. Internet Bank. Commer. 2014, 19, 1-21.

41. Chen, C.S. Perceived risk, usage frequency of mobile banking services. Manag. Serv. Qual. 2013, 23, 410-436. [CrossRef]

42. Gakere, G.M. An Investigation on the Effects of Mobile Banking Services on Service Quality among United States International University Students. Master's Thesis, Chandaria School of Business, United States International University-Africa, Nairobi, Kenya, 2016.

43. Govender, I.; Sihlali, W. A study of mobile banking adoption among university students using an extended TAM. Mediterr. J. Soc. Sci. 2014, 5, 451-459. [CrossRef]

44. Malaquias, R.F.; Hwang, Y. An empirical study on trust in mobile banking: A developing country perspective. Comput. Hum. Behav. 2016, 54, 453-461. [CrossRef]

45. Ennew, C.T.; Waite, N. Financial Services Marketing: An International Guide to Principles and Practice; ButterworthHeinemann Elsevier: Oxford, UK, 2007.

46. Mersha, T.; Adlakha, V. Attributes of service quality: The consumers' perspective. Int. J. Serv. Ind. Manag. 1992, 3, 34-45. [CrossRef]

47. Culiberg, B.; Rojšek, I. Identifying service quality dimensions as antecedents to customer satisfaction in retail banking. Econ. Bus. Rev. 2010, 12, 151-166.

48. Choudhury, K. Service quality and customers' purchase intentions: An empirical study of the Indian banking sector. Int. J. Bank Mark. 2013, 31, 529-543. [CrossRef]

49. Sangeetha, J.; Mahalingam, S. Service quality models in banking: A review. Int. J. Islam. Middle East. Financ. Manag. 2011, 4, 83-103. [CrossRef]

50. Nisha, N. Exploring the dimensions of mobile banking service quality: Implications for the banking sector. Int. J. Bus. Anal. 2016, 3, 60-76. [CrossRef]

51. Malviya, S. Exploring mobile banking service quality dimensions for public and private sector banks in Indore district of Madhya Pradesh. Int. J. Adv. Res. Comput. Sci. Manag. Stud. 2015, 3, 243-252.

52. Ozer, A.; Argan, M.T.; Argan, M. The effect of mobile service quality dimensions on customer satisfaction. Procedia Soc. Behav. Sci. 2013, 99, 428-438. [CrossRef]

53. Hamzah, Z.L.; Lee, S.P.; Moghavvemi, S. Elucidating perceived overall service quality in retail banking. Int. J. Bank Mark. 2017, 35, 781-804. [CrossRef]

54. Alalwan, A.A.; Dwivedi, Y.K.; Rana, N.P.P.; Williams, M.D. Consumer adoption of mobile banking in Jordan: Examining the role of usefulness, ease of use, perceived risk and self-efficacy. J. Enterp. Inf. Manag. 2016, 29, 118-139. [CrossRef]

55. Munoz-Leiva, F.; Climent-Climent, S.; Liébana-Cabanillas, F. Determinants of intention to use the mobile banking apps: An extension of the classic TAM model. Span. J. Market. ESIC 2017, 21, 25-38. [CrossRef]

56. Wessels, L.; Drennan, J. An Investigation of Consumer Acceptance of M-Banking in Australia. In Proceedings of the Australian and New Zealand Marketing Academy Conference 2009: Sustainable Management and Marketing, Melbourne, Victoria, 30 November-2 December 2009; Luxton, S.S., Ed.; Promaco Conventions Pty Ltd.: Bateman, Australia, 2009; pp. 1-7.

57. Peevers, G.; Douglas, G.; Jack, M.A. A usability comparison of three alternative message formats for an SMS banking service. Int. J. Hum. Comput. Stud. 2008, 66, 113-123. [CrossRef]

58. Davis, F.D.; Bagozzi, R.P.; Warshaw, P.R. User acceptance of computer technology: A comparison of two theoretical models. Manag. Sci. 1989, 35, 982-1003. [CrossRef]

59. Hayashi, F. Mobile payments: What's in it for consumers? Econ. Rev. Fed. Reserve Bank Kans. City 2012, 97, 35-66.

60. Gu, J.C.; Lee, S.C.; Suh, Y.H. Determinants of behavioral intention to mobile banking. Expert Syst. Appl. 2009, 36, 11605-11616. [CrossRef]

61. Boonsiritomachai, W.; Pitchayadejanant, K. Determinants affecting mobile banking adoption by generation $\mathrm{Y}$ based on the unified theory of acceptance and use of technology model modified by the technology acceptance model concept. Kasetsart J. Soc. Sci. 2017, 40, 349-358. [CrossRef]

62. Huili, Y.; Shanzhi, L.; Yinghui, Y. A study of user adoption factors of mobile banking services based on the trust and distrust perspective. Int. Bus. Manag. 2013, 6, 9-14.

63. Shanka, M.S. Bank service quality, customer satisfaction and loyalty in Ethiopian banking sector. J. Bus. Admin. Manag. Sci. Res. 2012, 1,1-9. 
64. Bontis, N.D.; Booker, L.D.; Serenko, A. The mediating effect of organizational reputation on customer loyalty and service recommendation in the banking industry. Manag. Decis. 2007, 45, 1426-1445. [CrossRef]

65. Hair, J.F.; Black, W.C.; Babin, B.J.; Anderson, R.E.; Tathan, R.L. Multivariate Data Analysis; Prentice Hall: Upper Saddle River, NY, USA, 2006.

66. Costello, A.B.; Osborne, J. Best practices in exploratory factor analysis: Four recommendations for getting the most from your analysis. Pract. Assess. Res. Eval. 2005, 10, 1-9.

67. Feldt, L.S.; Kim, S. A comparison of tests for equality of two or more independent alpha coefficients. J. Educ. Meas. 2008, 45, 179-193.

68. De Vaus, D. Research Design in Social Research; Sage Publications: London, UK, 2001.

69. Hooper, D.; Coughlan, J.; Mullen, M.R. Structural equation modelling: Guidelines for determining model fit. Elecron. J. Bus. Res. Methods 2008, 6, 53-60.

70. Marrara, S.; Pejic-Bach, M.; Seljan, S.; Topalovic, A. FinTech and SMEs—the Italian case. In FinTech as a Disruptive Technology for Financial Institutions; Rafay, A., Ed.; IGI-Global: Hershey, PA, USA, 2019; pp. 42-60.

71. Dean, D.H. Consumer perception of corporate donations effects of company reputation for social responsibility and type of donation. J. Advert. 2003, 32, 91-102. [CrossRef]

72. Carter, R.B.; Dark, F.H. An empirical examination of investment banking reputation measures. Financ. Rev. 1992, 27, 355-374. [CrossRef]

73. Casalo, L.V.; Flavián, C.; Guinalíu, M. The role of security, privacy, usability and reputation in the development of online banking. Online Inf. Rev. 2007, 31, 583-603. [CrossRef]

74. Dowling, G.R.; Gardberg, N.A. Keeping score: The challenges of measuring corporate reputation. In The Oxford Handbook of Corporate Reputations; Pollock, T.G., Barnett, M.L., Eds.; Oxford University Press: Oxford, UK, 2012; pp. 34-68.

(C) 2020 by the authors. Licensee MDPI, Basel, Switzerland. This article is an open access article distributed under the terms and conditions of the Creative Commons Attribution (CC BY) license (http://creativecommons.org/licenses/by/4.0/). 